\title{
RISK EVALUATION IN THE BUSINESS OF MEDIUM-SIZED COMPANIES ON THE EXAMPLE OF THE REPUBLIC OF SERBIA
}

\author{
Dragan Djuranovic, PIM University Banja Lulka, Despota Stefana Lazarevica bb, Banja Luka, 78000, Bosnia \\ and Herzegovina, gandra.dj@hotmail.com
}

Slobodan Popovic, JKP Gradsko Zelenilo Novi Sad, Mladena Leskovca 1, 21000 Novi Sad, Republic of Serbia, Corresponding Author slobodan.popovic49@gmail.com

\begin{abstract}
Transition economies are moving towards the formation of a market economy where private ownership essentially dominates and where there are developed market institutions.

In such economies, the management of medium and small enterprises should be based on respect for all target functions in the mentioned enterprises. Doing business in such companies is essentially aimed at maximizing profits, and this is achieved by top management primarily through good and quality management.

The financial position of the company is the most important indicator of the financial health of the company. The financial position of the company is seen in the numerous financial reports that top management receives from all parts of the company on a daily basis. At the same time, they can be seen in the total financial and other possibilities available to the medium-sized company in the given observation interval.

Creating new company values implies the simultaneous creation of a possible competitive advantage over other companies that operate similarly or operate in the same industry. The goal of good management by top management is to maximize the economic effects of the company.
\end{abstract}

Keywords: management, value, risk, financial report.

\section{INTRODUCTION}

In the business of medium-sized companies in transition economies, various influences can be observed, which are manifested in the financial statements that are continuously received 
by top management. In addition, different types of dependencies can be established between economic phenomena that have arisen in the process of managing different companies [1-7]. In this paper, the authors pointed out the importance of valid financial and any other reporting of top management, especially medium-sized companies. The company's operations require new investments and new spending of liquid assets of numerous shareholders and other creditors of the company.

Transition economies strive to develop as developed market institutions as possible [8-12], all with the aim of general development of the state and general prosperity. In such planned conditions, a large number of medium and small companies are building their prosperity. It is generally known that the goal function of a company is to maximize profits by increasing production results [13-16].

In order to be able to perform the function of company development, it is necessary to monitor the financial position of the company at all times. Therefore, the top management of the company requires all parts of the company to submit regular and periodic financial reports, which are essentially the most important indicator of the financial health of the company and which speaks primarily about the financial capabilities of the company at a given time. The evaluation of economic effects is visible in the financial reporting that the company submits to the state authorities in the form of the final business account for a certain business year.

Management tries to consider as many risk factors as possible in the investment evaluation process that can have an impact on the overall business of the company [17-21]. Fair compensation of possible risks to the company's operations can also have a positive effect on new (future) investments [22-25].

This is important to point out due to the fact that good and honest financial reporting can reduce the distrust and antagonism of shareholders and other creditors who invest in the company's operations. 


\section{DECISION-MAKING OF TOP MANAGEMENT WITH RESPECT OF BUSINESS RISKS FIRST OF ALL MEDIUM ENTERPRISES ON THE EXAMPLE OF THE REPUBLIC OF SERBIA}

Business decision-making in companies by top management should include a large number of risks that may more or less affect the overall business of the company. This can mostly directly affect the general business of the company, regardless of its market position, size, activity in which it carries out the majority of activities, etc.

In the continuation of the study, the authors gave a possible presentation in the form of a schematic presentation 1 and which refers to the decision-making of top management while taking into account the business risk, primarily of medium-sized companies on the example of the Republic of Serbia.

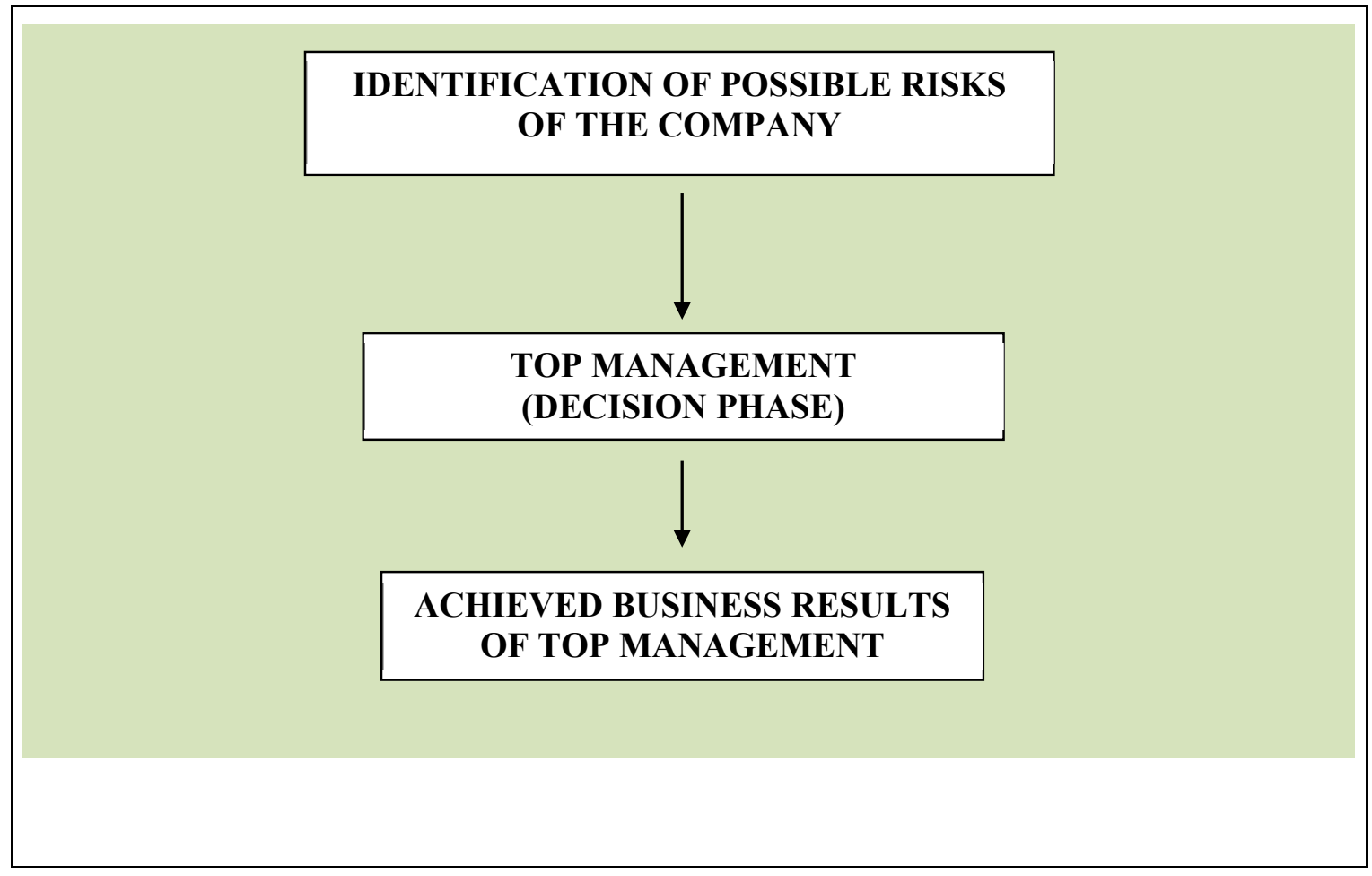

Fig. 1: Presentation of the decision-making scheme with the identification of risks to the company's operations 


\section{GENERAL RISK FACTORS (ACTIVITIES) THAT MAY INFLUENCE DECISION-MAKING WITH EMPHASIS OF RISK ASSESSMENT}

General risk factors (activities) that can influence decision-making with emphasis of risk assessment are one of the parameters that can influentially make business important decisions of top management in a large number of companies.

This primarily refers to the business of medium-sized companies.

The paper gives an example of the listed factors influencing business decision - making in the Republic of Serbia on the example of a randomly selected medium - sized company that has been operating positively without interruption since 1967 .

The risk assessment was given by the representatives of the top management and is given in the presentation of Table 1 as the average assessment of 7 representatives of the top management.

Table 1: Overview of general risk factors (activities) that can influence decision-making with expression of risk assessment by the top management of the surveyed company

\begin{tabular}{|c|c|c|}
\hline $\begin{array}{c}\text { REGULAR } \\
\text { NUMBER }\end{array}$ & NAME OF SECTOR/ACTIVITY & $\begin{array}{c}\text { RISK } \\
\text { ASSESSMENT }\end{array}$ \\
\hline 1 & Public enterprise sector & 1 \\
\hline 2 & Finance and insurance sector & 2 \\
\hline 3 & Manufacturing industry & 2 \\
\hline 4 & Wholesale and retail trade & 2 \\
\hline 5 & Traffic & 3 \\
\hline 6 & Mining & 3 \\
\hline 7 & Agriculture, & 3 \\
\hline 8 & forestry and fishing & 2 \\
\hline 9 & Bankrupt companies & Other \\
\hline
\end{tabular}




\section{INTERNAL FACTORS OF COMPANY ORGANIZATION AS A FACTOR INFLUENCING THE DECISION-MAKING OF TOP MANAGEMENT}

Internal factors of the organization of the company as a factor influencing the decisionmaking of top management can have a great influence on making valid decisions of top management.

In Table 2, the authors give an overview of some risks that may have an impact on the company's operations.

The last column shows the average value of risk of 7 participants or 7 representatives of the top management of the surveyed company.

Table 2: Overview of internal factors of company organization as a factor influencing the decision-making of top management

\begin{tabular}{|c|c|c|}
\hline \multicolumn{2}{|c|}{ INTERNAL FACTORS OF ENTERPRISE ORGANIZATION } \\
\hline Risk factor & \multicolumn{1}{|c|}{ Description } & $\begin{array}{c}\text { Value expressed risk } \\
\text { for the company's } \\
\text { operations }\end{array}$ \\
\hline $\begin{array}{c}\text { Internal audit mechanism built } \\
\text { Existence of an obligation to adjust } \\
\text { accounting policies }\end{array}$ & $\begin{array}{c}\text { Lack of a defined system of internal controls } \\
\text { and audits by management } \\
\text { total maintenance costs and to reconcile them } \\
\text { with the book value of assets with which the } \\
\text { company operates }\end{array}$ & 3 \\
\hline & $\begin{array}{c}\text { Lack of accounting obligation to monitor } \\
\text { Total risk }\end{array}$ & \\
\hline
\end{tabular}

\section{CONCLUSIONS}

The research in this paper was done with the aim of emphasizing the importance of risk implementation as a factor that will significantly reveal the connection between real business, especially medium-sized companies in transition countries, and the overall business of top management. 
The importance of detecting business risks is a constant, which was emphasized by the authors. At the same time, they point out that the disclosure of the total risk to the company's operations is posed as one of the important issues, especially for numerous shareholders and other creditors of the company, because their funds are managed by the company's top management.

At the same time, top management should focus its important business decisions on establishing the best possible control, primarily risk management in the company, especially if it is a business of a company in a transition country such as the Republic of Serbia.

Financial statements that include realistic reporting of the company's top management on significant risks are the basis for realistic and valid decision-making that will have a positive effect on the overall business of the company.

\section{REFERENCES}

[1] Van, Horne J., \& Wachowicz, J. (2007). Fundamentals of financing management, Data status, Beograd.

[2] Brigham, E., \& Gapenski L. (1994). Financial Managemement, The Dryden Press, Harcourt Brace College Publishers, Orlando.

[3] Majstorović, A., Milojević, I., (2007). Analiza finansijskog kapaciteta u funkciji realizacije javnih nabavki privrednog subjekta, Računovodstvo, br. 3-4/2007, Savez računovođa i revizora Srbije, Beograd.

[4] Popović, S., Novaković, S., Đuranović, D., Mijić, R., Grublješić, Ž, Aničić, J., Majstorović, A. (2017). Application of international accounting standard-16 in a public company with predominantly agricultural activities, Economic Research-Ekonomska Istraživanja, 30(1): 1850-1864.

[5] Weis, B. (2003). Modern Management in the Budgetary System, Grace and White, Inc.

[6] Cantino, V. (2009). Korporativno uptravljanje, merenje performansi i normativna usaglašenost sistema internih kontrola, Beograd, Data Status.

[7] Wilkinson, J. etc. (1999). Accounting Information Systems, 4th Edition, Arizona State University.

[8] Mijić, R., Popović, S. (2016). Finansijsko Računovodstvo, Banja Luka: City print. 
[9] Majstorović, A., Popović, S., Volf, D. (2015). Teorija i politika bilansa, drugo izmenjeno i dopunjeno izdanje, Novi Sad: Feljton.

[10] Popović, S. (2014). Socio-ekonomski faktori ograničenja razvoja agrara, Monografija, Fimek, Novi Sad, Srbija.

[11] Popović, S., Ugrinović, M., Tomašević, S. (2015). Upravljanje menadžmenta poljoprivrednog preduzeća preko praćenja ukupnih troškova održavanja traktora, Poljoprivredna tehnika, 2: 101-106.

[12] Popović, S., Ugrinović, M., Tomašević, S. (2015). Management of Agricultural Enterprises by Means of Fair Financial Reporting in Accordance with International Standards of the Finance and Accounting Reporting, CDQM, Number 3: 24-30.

[13] Popović, S., Mijić, R., Grublješić, Ž. (2014). Interna kontrola i interna revizija u funkciji menadžmenta. Škola Biznisa, 1, 95-107.

[14] Popović, S., Tošković, J., Majstorović, A., Brkanlić, S., Katić, A. (2015). The importance of continuous audit of financial statements of the company of countries joining the EU, Annals of the „Constantin Brâncuşi”" University of Târgu Jiu, Economy Series, Special Issue, 241-246.

[15] Bojović, R., Popović, V., Ikanović, J., Živanović, Lj., Rakaščan, N., Popović, S., Ugrenović, V \& Simić, D. (2019). Morphological characterization of sweet sorghum genotypes acrossen vironments, The J. Anim. Plant Sci. 29(3).

[16] Popović, S. (2015). Implementacija heterogenih rizika u radu interne revizije, Revizor 69.

[17] Vitomir, J., Tomaš-Miskin, S., Ivić, M., Popović, S. (2020). Implementation of the Tender by the Municipal Service Administration from the Aspect of Management in the Municipalities of the Republic of Serbia, Lex Localis - Journal of Local Self-Government, 8, 3: $469-486$.

[18] Terzić, D., Popović, V., Malić, N, Ikanović, J, Rajičić, V., Popović, S., Lončar, M \& Lončarević. V. (2019). Effects of long-term fertilization on yield of siderates andorganic matter content of soil in the process of recultivation. The J. Anim. Plant Sci. 29(3).

[19] Radović, M., Vitomir, J. and Popović, S. (2019). The Importance of Implementation of Internal Audit in Enterprises Founded by the Republic of Serbia, Lex Localis - Journal of Local Self-Government, 17, 4: 1001-1011. 
[20] Bjelica, B., Bakmaz, O., Mijić, R., Popović, S. and Popović, V. (2017). The implementation of heterogeneous risk to the company's operations and transition countries respecting the behavior of agricultural enterprises in the republic of Serbia. Annals, Economy Series, 3 .

[21] Han, Y. (2017). Has the "Non-Clean" Internal Control Audit Opinion Received Sufficient Attention?-Evidence from the Perspective of Creditors, Journal of Central University of Finance and Economics, 8:57-64.

[22] Radović, M., Vitomir, J. \& Popović, S. (2021). Impact of internal control in enterprises founded by local self-government units: the case of Republic of Serbia, Inzinerine Ekonomika-Engineering Economics, 32(1): 82-90.

[23] Ugrenović, V., Popović, V., Ugrinović, M., Filipović, V., Mačkić, K., Ljubičić, N., Popović, S. \& Lakić, Ž. (2021). Black Oat (Avena strigosa Schreb.) Ontogenesis and Agronomic Performance in Organic Cropping System and Pannonian Environments, Agriculture 2021, 11(1): 55.

[24] Rodriguez, M., Miguel, Sanchez, L., Cejudo, E. and Antonio, C. (2019). Variety in local development strategies and employment: LEADER programme in Andalusia. Agric. Econ. Czech, 65: 43-50.

[25] White, G., Sondhi, A. \& Fried, H. (2003). The Analysis and Use of Financial Statements, 3rd Edition, Grace and White, Inc. 